Article

\title{
Networking for Educational Innovations: A Bibliometric Survey of International Publication Patterns
}

\author{
Kai-Yu Tang ${ }^{1}\left(\mathbb{D}\right.$, Chun-Hua Hsiao ${ }^{2} \mathbb{D}$ and Yu-Sheng Su ${ }^{3, * \mathbb{D}}$ \\ 1 Department of International Business, Ming Chuan University, Taipei City 111, Taiwan \\ 2 Department of Marketing, Kainan University, Taoyuan City 338, Taiwan \\ 3 Department of Computer Science and Engineering, National Taiwan Ocean University, \\ Keelung City 202, Taiwan \\ * Correspondence: ntouaddisonsu@gmail.com
}

Received: 10 August 2019; Accepted: 21 August 2019; Published: 24 August 2019

\begin{abstract}
The emergence of networking has been viewed as a critical educational innovation. To highlight some innovations in educational networking (EN) research, this paper provides a bibliometric overview of international EN research from 2000 to 2018. Based on a keyword search, a total of 1005 journal articles with 13,803 citations were obtained. Through careful bibliometric analyses, three main results were concluded. (1) The growth of EN articles and authors was up by 1.5 times from the first decade (2000-2009) to the current one (2010-2018). (2) The most influential journals (over 300 citations) were identified. The research scope covers education technology, higher education, education policy, and even AIDS (acquired immune deficiency syndrome) education. (3) Based on some popular bibliometric indicators, the changes of research trends can be seen from the comparison of the main streams, which are identified from the most influential articles. Classification of the main research streams was presented, providing a typological understanding of the EN literature. In the first decade of research, the two articles which ranked first in terms of overall citations and average citations are Horvat et al. (2003) (232 times) and Coburn and Russell (2008) (17.6 times), respectively. In the last decade, the article by Roblyer et al. (2010) received both the highest number of citations (407) and average citations (45.2). Finally, the main ideas of highly-cited articles were categorized into three research streams. While the EN research of the earlier decade focused on interpersonal relationships, that of the recent decade emphasized on some innovative networking approaches, such as social media for learning, and network-based methodologies. Further discussions are provided.
\end{abstract}

Keywords: educational innovations; educational networking research; bibliometric survey; international publication patterns

\section{Introduction}

With the emergence of social media (e.g., Facebook), the term "network" or "networking" has become popular and has even been applied as an innovative tool for learning in the field of education. Numerous attentions on these network-related topics not only benefited the industrial development, but it has also attracted considerable academic researchers. According to the topics search on the Web of Science (Wos), "network" or "networking" research has shared over $4.5 \%$ of the journal articles in the category of education and educational research (the search was conducted on 12 February 2019), indicating a high relevance and importance of networking research in the educational domain.

Networking points to a process of information sharing and communication with some others, including collaborative learning community [1], social networking on learning [2-4], and the method 
of network analysis [5-7]. Holcomb and his colleagues defined "educational networking" as the use of social networking technologies for educational purposes [8]. Network, on the other hand, refers to "a huge system consists of many similar parts so that they can share information" (according to the Cambridge dictionary). In the educational context, a network can be a group of people with the same specialties, such as personal professional network [9]. In this study, "network" and "networking" are considered as two specialized but highly-correlated terms in the digital age. Therefore, we include these two concepts and define "educational networking" as a group or system of interconnected people or things for educational purposes (referring to the definition of Oxford) for the following analysis.

In the recent reviews of educational networking (EN) research, some studies have focused on the use of social networking technology (e.g., Facebook) as a technology-enhanced learning tool for educational purposes from various perspectives. For example, Macià and García (2016) reviewed 147 journal articles (2012-2015) which explored the influences of informal online networking communities (e.g., Facebook) on the learning environment in secondary education [10]. They concluded that the pedagogical affordances of Facebook could be partially implemented. Likewise, Chugh and Ruhi's (2018) narrative review pointed out that social media (e.g., Facebook) can be used as an educational tool to increase teacher-student and student-student interactions in higher education [11]. Niu (2019) further presented four research directions regarding the adoption of Facebook for academic purposes, including an in-depth examination of learning using Facebook, quasi- or true experimental design, the address of potential response bias, adoption of content analysis [12].

Another two reviews, on the other hand, focused on network-based platforms for learning. Amara et al. (2016) reviewed the issues of group formation in mobile computer-supported collaborative learning (CSCL) contexts [13]. Some recommendations for future research, such as group formation problems in CSCL environments, the customization of the grouping process, and the implementation of grouping algorithms and evaluation methods were provided. After reviewing 146 empirical studies (2014-2016) in the context of massive open online courses (MOOCs), Zhu et al. (2018) concluded that learner retention and motivation are the critical issues for networked learning [14].

Previous reviews have provided future directions for EN research. This paper; however, aims at providing an essential and systematic understanding of EN publication patterns in past two decades. In addition, the corresponding bibliometric data accompanied with large-scale citation evidence from 2000 to 2018 was collected together to profile critical publication patterns in EN research. Based on some popular bibliometric indicators, the most influential articles between each period of research were identified as the main streams for the comparison of the changes of research trends. Classification of the main research streams was also presented, providing another typological understanding of the EN literature.

Specifically, three research purposes of this present study are: (1) To calculate critical research statistics regarding the number of journal articles and authors involved in the EN area year by year. The non-repeated counts of the authors who appeared in the publication were used to reveal the actual scale and the new involvement of "the invisible colleagues of international EN publications" in each year of research; (2) to present a structural macro-view of the EN research by using bibliometric analysis to identify the most productive countries and influential journals in the EN literature; and (3) to take a close look at high-impact EN articles across two research decades (earlier decade: 2000-2009; recent decade: 2010-2018). The two periods were set to further investigate the decade changes in the main research streams from the earlier days of the dot-com era to the recent decade. The research streams were extracted and categorized from the high-impact EN articles in each period. The procedure of data retrieval from the WoS, the use of bibliometric analysis (e.g., h-index, g-index), and the coding scheme of contributing countries will be specified in the Data and Methodology section. Taken together, this paper provides a clear understanding of the status of EN research backed up with solid bibliometric evidence. 


\section{Methodology}

\subsection{The Process of Research Data Collection}

Since the nature of this paper is a research survey, the process of research data collection is crucial for a systematic overview of educational networking research. In this study, only high-quality journal articles were selected as the sources of the analysis. As such, we focused on the research articles published in the education and educational research (EER) journals, which are classified by the world-renowned research database, the Web of Science (WoS) [15]. The foundation of high-quality education journals meets the primary purpose of educational networking research in this study. To include as many research articles as possible, we did not limit the application fields. Instead, a straightforward term "network" was set as the keyword to search for articles in the education domain as the initial pool of research papers. However, a relevancy test based on citation relationships was conducted to secure the relatedness of the research data [16]. The test assumed that if an article is not cited or does not cite any other articles in the dataset, it is considered to be unrelated to the primary literature of analysis, and should; therefore, be excluded. It is especially accurate and effective when a large-scale set of citation links is collected as the basis for a test. Based on this systematic data collection approach, a total of 1005 educational networking articles with 13,803 received citations were obtained. The time-span of research was set from 2000 to 2018, and the collection of citation data was carried out over a period of 2 weeks and was completed on 12 February 2019.

\subsection{Bibliometric Analysis}

Bibliometric analysis is rooted in the library science of tracking citation relationships among journal publications [17]. The most powerful application of bibliometrics is known as science and social science citation indices (SCI and SSCI) in academic research. Some researchers have used bibliometrics to review EN literature. For example, Martí-Parreño et al. (2016) used bibliometric analysis to review 139 papers related to gamification in the education area from SCI and SSCI databases [18]. Hernández et al. (2017) conducted bibliometric analysis and author productivity analysis to analyze 226 papers of ICT-based learning from Scopus [19].

Based on the bibliometric analysis, we employed some citation statistics to observe the trends in educational networking publications, and to calculate the country productivity based on the affiliation of the first author. The statistics included total times cited, average times cited (per research period 2000-2009 and 2010-2018), and active year of publications. In addition, we applied two bibliometric indicators, h-index and g-index, to identify the most influential journals in the field as well as the articles with the greatest impact in each period. The h-index, first introduced by Hirsch (2005), provides an author-level metric that measures how many articles have each been cited at least $\mathrm{h}$ times [20]. For example, if an author has an h-index of 5, it means that the author's top five publications have been cited at least five times. The g-index provides in-depth understanding of how many articles are receiving together at least g-square (g2) citations [21]. This study adopted the two indices of the journal-level metric to identify the top-tier journals in EN research.

\section{Results and Discussions}

\subsection{The Statistics of Articles and Authors in Educational Networking Research}

To present the publication patterns of educational networking research, the distributions of published articles and participating authors in EN research were conducted. As shown in Figure 1, a clear upward trend in both lines was found.

Figure 1 shows a clear upward trend in the published articles and involved authors in the EN research. Overall, a total of $1005 \mathrm{EN}$ articles with 2343 authors were found. Note that in this study, non-repeated authors were counted to outline how many new researchers joined in EN research each year. As presented in Figure 1, more than 100 new authors (112, in upper line) participating in the EN 
publications first appeared in 2009, and more than 100 articles published in a single year first appeared in 2017 (107, in lower line). In the last five years (except 2014), more than 200 new authors participated in the EN study each year as shown in the map $(n=218,2015 ; n=201,2016 ; n=262,2017$; and $n=233$, 2018), indicating an active growth trend in the field.

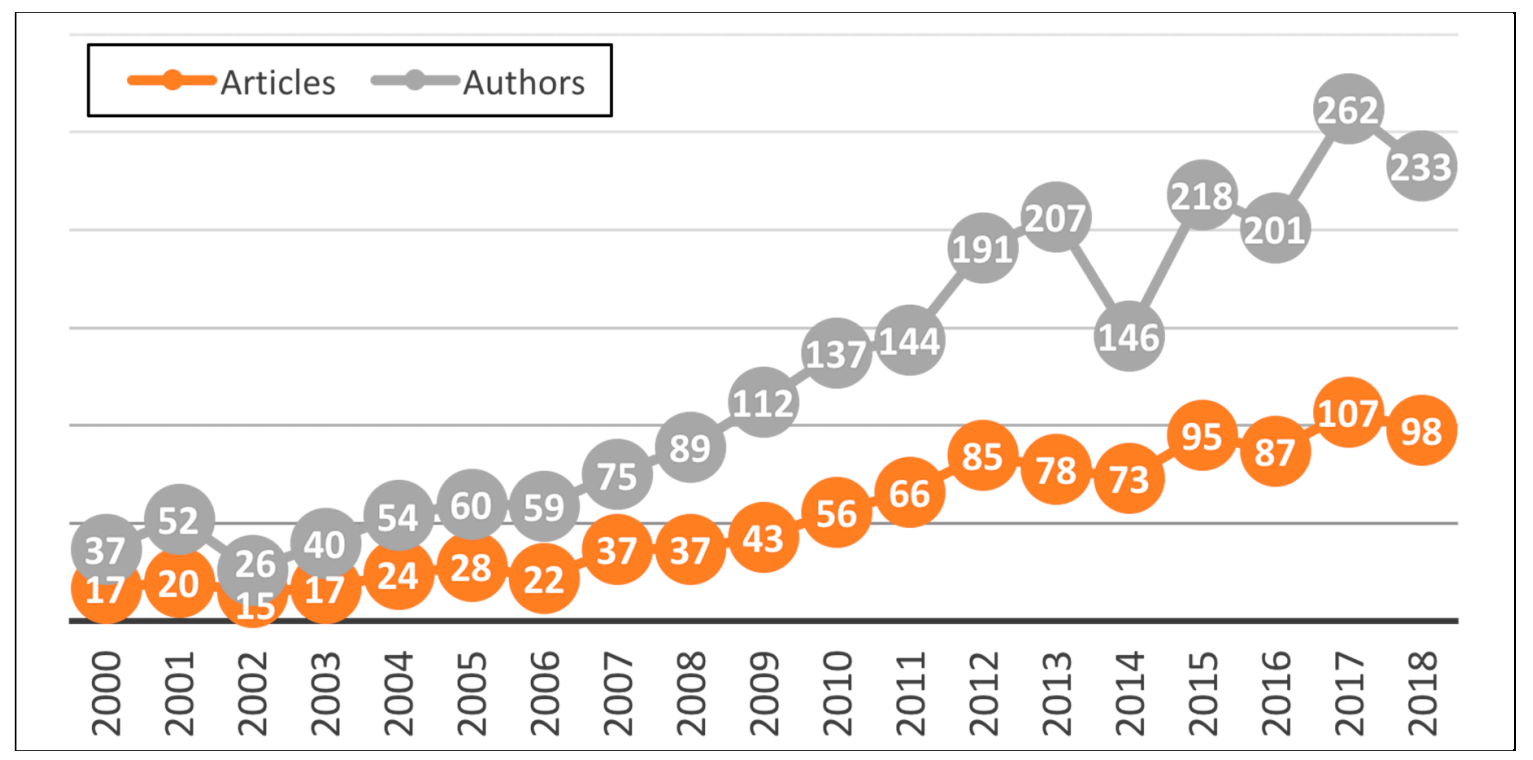

Figure 1. The growth statistics of educational networking research (2000-2018): Articles and authors.

\subsection{The Most Productive Countries in Educational Networking Research}

Table 1 presents another viewpoint of country productivity to reflect the EN publication patterns. In this study, we regard the affiliation of the first author as a contribution to the country. The information of author's affiliation was extracted from the bibliometric record on the Web of Science. This approach is relatively straightforward, because the first author is responsible for the entire article and; therefore, makes a significant contribution to the research. This idea is also applied in other bibliometric analysis, such as author co-citation analysis [22], and the feasibility has been confirmed in a recent educational review research [23]. As shown in Table 1, the top 10 productive countries in terms of EN publications are: the USA (328), UK (128), Spain (67), Australia (61), Taiwan (46), China (46), the Netherlands (41), Canada (33), Germany (32), and Turkey (30). The figures in the parentheses are the total EN articles published and led by the country's researchers. Note that all of 1005 articles were contributed by researchers from 53 countries.

Taking a close look, a total of $328 \mathrm{EN}$ articles were published by researchers in the United States, with almost $30 \%$ of publications surpassing other countries. The cumulative publications of the first decade (98 articles, 2000-2009) and the last decade (230 articles, 2010-2018) dominated the performance of other countries. More specifically, the researchers from the USA were also the most active authors of EN research published in each year. In this study, only the UK had the same publication pattern (having EN papers published in each year of research). Overall, the British researchers contributed 128 articles and the UK was ranked as the second most productive country in terms of EN publication. However, compared to $135 \%$ of the US growth trend in the two decades of publications, the productivity of the UK in EN research has decreased in recent years (72\%). There is a similar trend in the Netherlands (ranked seventh), where their growth rate of EN research across two decades was $56 \%$. Overall, the total amount of EN research in recent years (2010-2018) has reached 745 articles, which is almost $280 \%$ of the volume published in the previous decade $(n=260,2000-2009)$. This may also indicate that international EN research has become more competitive in recent years than in the previous period.

The productivity of EN research in Spain (ranked third), Australia (fourth), Taiwan (fifth), China (sixth), Canada (eighth), Germany (ninth), and Turkey (tenth) has significantly increased (at least 
$107 \%$ ) over the last decade; in particular, Spanish publications have grown by $917 \%$ in the EN field, which is almost 10 times the number of their publications in the first decade, following by researchers from Canada (271\%), Germany (257\%), Australia (159\%), and Taiwan (107\%). On the other hand, authors from China and Turkey had no published records in the previous decade, but in recent years they have contributed EN research almost every year. This shows that the importance of network research in education is increasingly of interest to researchers, especially in countries experiencing economic development.

Table 1. The most productive countries in educational networking research: Distribution.

\begin{tabular}{|c|c|c|c|c|c|c|c|c|c|c|c|c|c|c|c|c|c|c|c|c|}
\hline$\#$ & Country & 2000 & 2001 & 2002 & 2003 & 2004 & 2005 & 2006 & 2007 & 2008 & 2009 & 2010 & 2011 & 2012 & 2013 & 2014 & 2015 & 2016 & 2017 & 2018 \\
\hline 1 & USA (328) & 9 & 9 & 7 & 8 & 11 & 7 & 8 & 10 & 16 & 13 & 19 & 18 & 26 & 21 & 20 & 36 & 33 & 28 & 29 \\
\hline 2 & UK (128) & 2 & 1 & 4 & 4 & 3 & 6 & 6 & 4 & 6 & 11 & 11 & 9 & 18 & 3 & 9 & 8 & 5 & 8 & 10 \\
\hline 3 & Spain (67) & 0 & 0 & 1 & 1 & 0 & 1 & 1 & 1 & 0 & 1 & 3 & 4 & 2 & 19 & 8 & 5 & 8 & 9 & 3 \\
\hline 5 & Taiwan (46) & 1 & 3 & 2 & 0 & 2 & 2 & 0 & 3 & 2 & 0 & 4 & 3 & 3 & 2 & 3 & 3 & 4 & 6 & 3 \\
\hline 6 & China (46) & 0 & 0 & 0 & 0 & 0 & 0 & 0 & 0 & 0 & 0 & 2 & 0 & 2 & 2 & 4 & 5 & 5 & 12 & 14 \\
\hline 7 & Netherlands (41) & 1 & 0 & 0 & 2 & 2 & 3 & 1 & 4 & 1 & 2 & 2 & 3 & 4 & 4 & 3 & 1 & 2 & 1 & 5 \\
\hline 8 & Canada (33) & 1 & 1 & 0 & 0 & 0 & 0 & 1 & 1 & 3 & 0 & 3 & 3 & 2 & 1 & 1 & 5 & 4 & 5 & 2 \\
\hline
\end{tabular}

Total publications from the top 10 countries $=812$ (the remaining 53 countries $=193$ ). The total number of articles published in the first decade (2000-2009) is 213, and it is 599 in the current decade (2010-2018). The amounts of England, Scotland, North Ireland, and Wales are consolidated as the overall productivity of UK.

\subsection{The Most Influential Journals in Educational Networking Research}

Table 2 lists the most influential journals in EN research with the volume of total citations, g-index, h-index, and articles published from 2000 to 2018. In this study, a total of 196 journals published in educational networking research were found. However, only the journals with more than 300 total citations and within the top $10 \%$ of the g-index were listed. As a result, a total of 12 journals which met the criteria were selected. The results can be considered as the main streams of EN research over two decades. The analysis of the most influential journals also provides a global assessment of the scientific impact in the EN literature from the perspective of journal publications.

All in all, Computers $\mathcal{E}$ Education (C\&E) ranked first of 196 journals and published 61 articles with a high impact h-index of 21 and a g-index of 41 . The performance of $C \& E$ in both indicators was the highest in this study, where an h-index of 21 , which means that 21 articles published in C\&E have been cited at least 21 times. Additionally, the g-index of 41 indicates that over half of the EN articles published in this journal have been cited more than 41 square times, which is 1618 citations. In fact, all $61 \mathrm{EN}$ articles published in C\&E have received a total of 1780 citations. The citation counts were collected until 12 February 2019.

Next was Internet and Higher Education (IHE) with 18 articles, an h-index of 12, and a g-index of 18. Overall, articles published in this journal have been cited 904 times. However, according to the result of active years, the EN study published in IHE began in 2008, which is eight years later than C\&E. This may indicate that a new research trend of networking research focusing on the issues of internet use and higher education has emerged. British Journal of Educational Technology (BJET), ranked third in terms of the number of articles, published 38 articles with an h-index of 13 and a g-index of 21 and received 504 citations. The three leading journals covers the most critical research in technology-enhanced learning, network-based learning, and higher education.

Other journals with similar attributes and research scope are listed in Table 2 as well, for example, Journal of Computer Assisted Learning (JCAL), International Review of Research in Open and Distributed Learning (IRRODL), Educational Technology and Society (ET\&S), Studies in Higher Education (SHE), and Higher Education (HE), which ranked 5 and 7 to 10, respectively. Note that the IRRODL is the only open access journal in this top list. It focuses on openness of higher education, and some regional issues in networked learning, such as in Africa and Middle Eastern countries.

It is noteworthy that the bilingual research journal Comunicar, published in Spanish and English, is listed in fourth place in this analysis. The research scope of Comunicar focuses on communication 
and education (also known as educommunication), communication technology, and new languages. This journal has published $24 \mathrm{EN}$ articles with an h-index of 14 and a g-index of 22, receiving a total of 490 citations. Comunicar published its first EN-related article in 2011 (compared with other top 10 journals in Table 2). On the contrary, the American Journal of Education (AJE), one of the long-standing education journals, published six EN studies from 2003. This result highlights the emerging importance of networking research in education, even in educommunication areas.

Last, the AIDS Education and Prevention journal provides a particular application of networking research in the field of health education. Even though the network has some unique representations and traceable functions between nodes for the investigation of AIDS networks, the topics are sensitive and some articles are not as highly referenced as shown in the following analysis. As such, the main applications of EN research in this journal were noted here: personal networks [24], family and friendship networks [25], the use of social networking applications, and HIV prevention [26].

In sum, compared with the other 184 journals (with 6947 citations), the top 12 have received about half of the citations (6856), forming some of the main research streams in EN research. The analysis from the perspective of journals reveals some diversity in the interest in EN research. The details of the main research streams and some of the potential changes will be further discussed below by considering the top 10 influential articles over the past two decades.

Table 2. The most influential journals (cited over 300 times) in EN research: Bibliometric perspective.

\begin{tabular}{|c|c|c|c|c|c|c|c|}
\hline$\#$ & Name & $\begin{array}{l}\text { Total } \\
\text { Citations }\end{array}$ & g-Index & h-Index & $\begin{array}{l}\text { Total } \\
\text { Papers }\end{array}$ & $\begin{array}{c}\text { Average } \\
\text { Citations } \\
\text { (Yearly) }\end{array}$ & $\begin{array}{l}\text { Active } \\
\text { Years }\end{array}$ \\
\hline 1 & Computers $\mathcal{E}$ Education & 1780 & 41 & 21 & 61 & 93.7 & $2000-2018$ \\
\hline 2 & $\begin{array}{l}\text { Internet and Higher } \\
\quad \text { Education }\end{array}$ & 904 & 18 & 12 & 18 & 82.2 & 2008-2018 \\
\hline 3 & $\begin{array}{c}\text { British Journal of Educational } \\
\text { Technology }\end{array}$ & 544 & 21 & 13 & 38 & 30.2 & 2000-2017 \\
\hline 4 & Comunicar & 490 & 22 & 14 & 24 & 61.3 & 2011-2018 \\
\hline 5 & $\begin{array}{l}\text { Journal of Computer Assisted } \\
\text { Learning }\end{array}$ & 472 & 16 & 11 & 16 & 26.2 & 2001-2018 \\
\hline 6 & $\begin{array}{l}\text { Journal of Education Policy } \\
\text { International Review of }\end{array}$ & 427 & 15 & 9 & 15 & 22.5 & $2000-2018$ \\
\hline 7 & $\begin{array}{l}\text { Research in Open and } \\
\text { Distributed Learning }\end{array}$ & 418 & 20 & 10 & 27 & 41.8 & 2009-2018 \\
\hline 8 & $\begin{array}{c}\text { Educational Technology and } \\
\text { Society }\end{array}$ & 415 & 19 & 9 & 39 & 25.9 & 2003-2018 \\
\hline 9 & Studies in Higher Education & 399 & 19 & 10 & 23 & 28.5 & 2005-2018 \\
\hline 10 & Higher Education & 366 & 18 & 12 & 26 & 19.3 & 2000-2018 \\
\hline 11 & $\begin{array}{l}\text { AIDS Education and } \\
\text { Prevention }\end{array}$ & 338 & 18 & 9 & 18 & 18.8 & 2000-2017 \\
\hline 12 & $\begin{array}{l}\text { American Journal of } \\
\text { Education }\end{array}$ & 303 & 6 & 4 & 6 & 20.2 & 2003-2017 \\
\hline & Top $10 \%$ journals $(\mathrm{n}=12)$ & 6856 & & & 311 & & \\
\hline & Others (184 journals) & 6947 & & & 694 & & \\
\hline & Total (196 journals) & 13,803 & & & 1005 & & \\
\hline
\end{tabular}

\subsection{Research Trends and Changes: The Analysis of the Top 10 EN Articles over Two Decades}

In order to reveal some potential research trends and changes in the EN literature, the top 10 EN articles across two decades were identified and compared. As shown in Table 3; Table 4, the ranking of articles was conducted by sorting the average citations of each article published during 2000-2009 and 2010-2018. In the first period from 2000 to 2009 (Table 3), Coburn and Russell's research (2008) ranked first with an average of 17.6 citations per year [27]. This article explored how district education policies affect teachers' social networks in seeking teaching discussion with peers. Ranked in second place, Ball's (2009) paper addressed some types of privatization through education policy 
(16.2 citations per year) [28]. From a view of journal publications, the two highly-cited articles were both published in education policy journals. On the other hand, Computers $\&$ Education published three papers: Cho et al. (2007) (ranked third) [1] and Martínez et al. (2003) (ranked eighth) [7] both evaluated students' learning outcomes in a computer-supported collaborative learning (CSCL) environment; the research of Garcia et al. (2007) (ranked sixth) adopted the Bayesian network methodology to detect students' learning style in a Web-based education system [29]. In addition to the above CSCL research, de Laat et al. (2007) (ranked ninth) presented another type of CSCL paper [30]. They conducted a review to address how social network analysis (SNA) is applied in networked learning/computer-supported collaborative learning (NL/CSCL) research. In sum, the issues of educational policy and learning collaboration were the main camps of EN research in the first decade.

From the perspective of learning scaffolds, researchers considered social network technology as a scaffolding tool to facilitate students' learning. For example, Greenhow and Robelia (2009) (ranked fifth) was one of the early studies to explore the effect of using social network sites (SNSs) (i.e., MySpace) on learning [31]. From another angle, Zurita and Nussbaum (2004) (ranked 10th) confirmed the significant learning effects in a mobile learning environment by a wireless handheld network [32].

In terms of methodology, half of the highly-cited articles use qualitative methods, while the rest adopt quantitative approaches. Among the qualitative methods, the case study [27,33], interview and observation $[31,34]$ are the top used qualitative methods (four out of five articles). Another qualitative method is a state-of-the-art review, which has been adopted in Bell's research [28] for proposing some arguments of network governance in privatizing education. As the quantitative methods, most researchers utilize social network analysis as the primary method (three out of five articles) $[1,7,30]$. The rest of the two articles use Bayesian networks [29] and experimental design [32].

In addition to exploring students' learning outcomes, Penuel et al. (2009) (ranked seventh) analyzed teachers' professional interaction with peers (e.g., in meetings, staff rooms, and classrooms) [33]. They believed that this kind of social interaction helps to enact changes in school reforms. Another compelling article explores parental networks. Horvat et al. (2003) (ranked fourth) use ethnographic data to compare the power of parental network between middle-class and poor working-class parents [34]. They found that the network of middle-class parents is easier to have a contact and to mobilize the information with professionals and school officials than a network of poor working-class parents can function. It is worth mentioning that this article received the highest total citations of 232 in the first research period. 
Table 3. Top 10 articles in educational networking research: Impact and main ideas (2000-2009) (sorted by citations per year).

\begin{tabular}{|c|c|c|c|c|c|c|}
\hline$\#$ & Authors & Article title & Journal & Main ideas & Methodology & Citations * \\
\hline 1 & $\begin{array}{c}\text { Coburn, C.E.; Russell, } \\
\text { J.L. [27] }\end{array}$ & $\begin{array}{l}\text { District policy and teachers' } \\
\text { social networks }\end{array}$ & $\begin{array}{c}\text { Educational } \\
\text { Evaluation and Policy } \\
\text { Analysis (2008) }\end{array}$ & $\begin{array}{l}\text { Teachers' social networks; } \\
\text { district policy; curriculum } \\
\text { implementation }\end{array}$ & $\begin{array}{l}\text { Qualitative: Case } \\
\text { study }\end{array}$ & 194 (17.6) \\
\hline 2 & Ball, S.J. [28] & $\begin{array}{l}\text { Privatizing education, } \\
\text { privatizing education } \\
\text { policy, privatizing } \\
\text { educational research: } \\
\text { network governance and } \\
\text { the 'competition state' }\end{array}$ & $\begin{array}{l}\text { Journal of Education } \\
\text { Policy (2009) }\end{array}$ & $\begin{array}{l}\text { Network governance; } \\
\text { policy; politics; } \\
\text { privatization education; }\end{array}$ & $\begin{array}{l}\text { Qualitative: } \\
\text { State-of-the-art } \\
\text { review }\end{array}$ & $162(16.2)$ \\
\hline 3 & $\begin{array}{l}\text { Cho, H.C.; Gay, G.; } \\
\text { Davidson, B.; } \\
\text { Ingraffea, A. [1] }\end{array}$ & $\begin{array}{l}\text { Social networks, } \\
\text { communication styles, and } \\
\text { learning performance in a } \\
\text { CSCL community }\end{array}$ & $\begin{array}{c}\text { Computers \& } \\
\text { Education (2007) }\end{array}$ & $\begin{array}{l}\text { Computer-mediated } \\
\text { communication; } \\
\text { collaborative learning; } \\
\text { distance education and } \\
\text { tele-learning; distributed } \\
\text { learning environment; } \\
\text { social network analysis }\end{array}$ & $\begin{array}{l}\text { Quantitative: } \\
\text { Social network } \\
\text { analysis }\end{array}$ & $180(15.0)$ \\
\hline 4 & $\begin{array}{l}\text { Horvat, E.M.; } \\
\text { Weininger, E.B.; } \\
\text { Lareau, A. [34] }\end{array}$ & $\begin{array}{l}\text { From social ties to social } \\
\text { capital: Class differences in } \\
\text { the relations between } \\
\text { schools and parent } \\
\text { networks }\end{array}$ & $\begin{array}{c}\text { American } \\
\text { Educational Research } \\
\text { Journal (2003) }\end{array}$ & $\begin{array}{l}\text { Elementary education; } \\
\text { family-school; leisure } \\
\text { activities; parental } \\
\text { networks; qualitative } \\
\text { methods; social capital; } \\
\text { social class }\end{array}$ & $\begin{array}{l}\text { Qualitative: } \\
\text { Interview and } \\
\text { observation }\end{array}$ & $232(14.5)$ \\
\hline 5 & $\begin{array}{l}\text { Greenhow, C.; } \\
\text { Robelia, B. [31] }\end{array}$ & $\begin{array}{l}\text { Informal learning and } \\
\text { identity formation in online } \\
\text { social networks }\end{array}$ & $\begin{array}{l}\text { Learning, Media and } \\
\text { Technology (2009) }\end{array}$ & $\begin{array}{c}\text { Informal learning; identity; } \\
\text { social network sites } \\
\text { (MySpace pages); high } \\
\text { school students }\end{array}$ & $\begin{array}{l}\text { Qualitative: } \\
\text { Interview and } \\
\text { content analysis }\end{array}$ & 141 (14.1) \\
\hline 6 & $\begin{array}{l}\text { Garcia, P.; Amandi, } \\
\text { A.; Schiaffino, S.; } \\
\text { Campo, M. [29] }\end{array}$ & $\begin{array}{l}\text { Evaluating Bayesian } \\
\text { networks' precision for } \\
\text { detecting students' } \\
\text { learning styles }\end{array}$ & $\begin{array}{c}\text { Computers \& } \\
\text { Education (2007) }\end{array}$ & $\begin{array}{l}\text { Learning styles; student } \\
\text { modeling; Bayesian } \\
\text { networks; e-learning }\end{array}$ & $\begin{array}{l}\text { Quantitative: } \\
\text { Bayesian } \\
\text { networks }\end{array}$ & 160 (13.3) \\
\hline
\end{tabular}


Table 3. Cont.

\begin{tabular}{|c|c|c|c|c|c|c|}
\hline$\#$ & Authors & Article title & Journal & Main ideas & Methodology & Citations \\
\hline 7 & $\begin{array}{c}\text { Penuel, W.; Riel, M.; } \\
\text { Krause, A.; Frank, K. } \\
\text { [33] }\end{array}$ & $\begin{array}{l}\text { Analyzing teachers' } \\
\text { professional interactions in } \\
\text { a school as social capital: A } \\
\text { social network approach }\end{array}$ & $\begin{array}{l}\text { Teachers College } \\
\text { Record (2009) }\end{array}$ & $\begin{array}{l}\text { Teachers' professional } \\
\text { interactions; social capital; } \\
\text { teacher education }\end{array}$ & $\begin{array}{c}\text { Qualitative: Case } \\
\text { study }\end{array}$ & $130(13.0)$ \\
\hline 8 & $\begin{array}{l}\text { Martinez, A.; } \\
\text { Dimitriadis, Y.; Rubia, } \\
\text { B.; Gomez, E.; de la } \\
\text { Fuente, P. [7] }\end{array}$ & $\begin{array}{l}\text { Combining qualitative } \\
\text { evaluation and social } \\
\text { network analysis for the } \\
\text { study of classroom social } \\
\text { interactions }\end{array}$ & $\begin{array}{c}\text { Computers \& } \\
\text { Education (2003) }\end{array}$ & $\begin{array}{l}\text { Collaborative learning; } \\
\text { evaluation methods; } \\
\text { learning communities; } \\
\text { post-secondary education }\end{array}$ & $\begin{array}{l}\text { Quantitative: } \\
\text { Social network } \\
\text { analysis }\end{array}$ & $178(11.1)$ \\
\hline 9 & $\begin{array}{c}\text { De Laat, M.; Lally, V.; } \\
\text { Lipponen, L.; Simons, } \\
\text { R.J. [30] }\end{array}$ & $\begin{array}{l}\text { Investigating patterns of } \\
\text { interaction in networked } \\
\text { learning and } \\
\text { computer-supported } \\
\text { collaborative learning: A } \\
\text { role for social network } \\
\text { analysis }\end{array}$ & $\begin{array}{l}\text { International Journal } \\
\text { of } \\
\text { Computer-Supported } \\
\text { Collaborative } \\
\text { Learning (2007) }\end{array}$ & $\begin{array}{c}\text { Social network analysis; } \\
\text { multi-method analysis; } \\
\text { learning; teaching; learning } \\
\text { communities }\end{array}$ & $\begin{array}{l}\text { Quantitative: } \\
\text { Social network } \\
\text { analysis }\end{array}$ & $114(9.5)$ \\
\hline 10 & $\begin{array}{c}\text { Zurita, G.; Nussbaum, } \\
\text { M. [32] }\end{array}$ & $\begin{array}{l}\text { A constructivist mobile } \\
\text { learning environment } \\
\text { supported by a wireless } \\
\text { handheld network }\end{array}$ & $\begin{array}{l}\text { Journal of Computer } \\
\text { Assisted Learning } \\
\text { (2004) }\end{array}$ & $\begin{array}{c}\text { Collaboration; } \\
\text { constructivist; wireless } \\
\text { handheld network for } \\
\text { learning; mobile } \\
\text { computer-supported } \\
\text { collaborative learning }\end{array}$ & $\begin{array}{l}\text { Quantitative: } \\
\text { Experimental } \\
\text { design }\end{array}$ & $112(7.5)$ \\
\hline
\end{tabular}

* The citations per year are presented in parentheses. CSCL refers to computer-supported collaborative learning. 
Table 4 shows a close look at the top 10 articles in the recent era from 2010 to 2018. Compared with the previous research decade, the main difference in this decade of research is that social networking platforms are heavily used for teaching purposes. Among various social networking sites (SNSs), Facebook has proven to be the most popular in both practical social applications and in academic research. In the recent years of analysis, Roblyer et al. (2010) ranked first for total citation counts and average citations (407 and 45.2, respectively) [35]. They found that students use Facebook extensively to support their classroom assignments. Other studies have also confirmed the effectiveness of social networking engagement (e.g., on Facebook) on students' learning outcomes [36,37] (ranked fifth and sixth, respectively) and social acceptance [38,39] (ranked third and seventh, respectively). Moreover, Kop's research review (2011) (ranked fourth) also emphasized the important impact of SNSs for educational innovations and raised some questions and challenges whereby open online networks might prevent learners from having a quality learning experience [40].

Table 4 also reveals some research trends for professional learning networks (PLNs) and social gamification in learning. From the perspective of teachers' professional growth; however, some evidence from recent studies was found. Veletsianos and Kimmons (2013) (ranked eighth) investigated teaching faculty's online practices and the use of SNSs for their teaching purposes and personal connections [41]. Based on several interviews, they found that both synergies as well as tensions existed for networking technology and professional purposes, such as teaching and research needs. Moreover, Trust et al. (2016) (ranked ninth) also confirmed the relationships between the use of PLNs and teacher development, including pedagogical practice [42].

Another trend regarding the issue of using SNSs and gamification approach for learning, the research team led by de-Marcos has contributed two comparative articles. The former research (de-Marcos et al., 2014) (ranked second) concluded that social networks and gamification approaches performed better in academic achievement than traditional e-learning approaches, but not in assessing knowledge [2]. Another study by de-Marcos et al. (2016) (ranked tenth) further confirmed that social gamification has achieved better results on the immediacy and all types of assessments [3].

In terms of methodology, five out of ten highly-cited articles are quantitative research $[2,3,35,37,39]$, three are qualitative research [36,41,42], and the remaining two use mix method [38,40]. Among the quantitative studies, five conduct survey method [35,37,39], and two adopt experiential design [2,3]. While most quantitative survey methods are descriptive statistics [37,39], Roblyer et al. (2010) performed some nonparametric analyses (e.g., Pearson Chi-square test) to analyze ordinal nature of data [35]. In addition, Yu et al. (2010) mixed structural equation modeling (SEM) and focus group to test the model of online social networking impacts [38]. Regarding the qualitative methods, focus group appears to be the most popular method to explore more in-depth information $[36,38,40]$. The other two qualitative methodologies are phenomenological method [41] and thematic analysis [42]. While Veletsianos and Kimmons (2013) adopted phenomenological interview to obtain the lived experiences of university faculty with social networking sites [41], Trust et al. (2016) conducted a thematic analysis to identify and explore patterns of professional learning networks from open-ended survey items [42]. 
Table 4. Top 10 articles in educational networking research: Impact and main ideas (2010-2018) (sorted by citations per year).

\begin{tabular}{|c|c|c|c|c|c|c|}
\hline$\#$ & Authors & Article title & Journal & Main ideas & Methodology & Citations \\
\hline 1 & $\begin{array}{l}\text { Roblyer, M.D.; } \\
\text { McDaniel, M.; Webb, } \\
\text { M.; Herman, J.; Witty, } \\
\text { J.V. [35] }\end{array}$ & $\begin{array}{l}\text { Findings on Facebook in } \\
\text { higher education: A } \\
\text { comparison of college } \\
\text { faculty and student uses } \\
\text { and perceptions of social } \\
\text { networking sites }\end{array}$ & $\begin{array}{l}\text { Internet and Higher } \\
\text { Education (2010) }\end{array}$ & $\begin{array}{c}\text { Social networking; } \\
\text { Facebook; instructional } \\
\text { technologies; online survey; } \\
\text { technology adoption } \\
\text { between college faculty and } \\
\text { student uses }\end{array}$ & $\begin{array}{c}\text { Quantitative: } \\
\text { Survey (Pearson } \\
\text { Chi square tests) }\end{array}$ & $407(45.2)$ \\
\hline 2 & $\begin{array}{c}\text { De-Marcos, L.; } \\
\text { Dominguez, A.; } \\
\text { Saenz-de-Navarrete, } \\
\text { J.; Pages, C. [2] }\end{array}$ & $\begin{array}{c}\text { An empirical study } \\
\text { comparing gamification } \\
\text { and social networking on } \\
\text { e-learning }\end{array}$ & $\begin{array}{c}\text { Computers \& } \\
\text { Education (2014) }\end{array}$ & $\begin{array}{l}\text { Gamification; playful } \\
\text { design; social network on } \\
\text { e-learning; motivation; } \\
\text { learning performance }\end{array}$ & $\begin{array}{c}\text { Quantitative: } \\
\text { Experimental } \\
\text { design (pre-test, } \\
\text { post-test } \\
\text { experimental) }\end{array}$ & $111(22.2)$ \\
\hline 3 & $\begin{array}{l}\text { Yu, A.Y.; Tian, S.W.; } \\
\text { Vogel, D.; Kwok, } \\
\text { R.C.W. [38] }\end{array}$ & $\begin{array}{c}\text { Can learning be virtually } \\
\text { boosted? An investigation } \\
\text { of online social networking } \\
\text { impacts }\end{array}$ & $\begin{array}{c}\text { Computers \& } \\
\text { Education (2010) }\end{array}$ & $\begin{array}{c}\text { Socialization; learning } \\
\text { outcomes; e-learning }\end{array}$ & $\begin{array}{l}\text { Mix methods: } \\
\text { Focus group, } \\
\text { survey (structural } \\
\text { equation } \\
\text { modeling) }\end{array}$ & $147(16.3)$ \\
\hline 4 & Kop, R. [40] & $\begin{array}{l}\text { The challenges to } \\
\text { connectivism learning on } \\
\text { open online networks: } \\
\text { Learning experiences } \\
\text { during a massive open } \\
\text { online course }\end{array}$ & $\begin{array}{c}\text { International Review } \\
\text { of Research in Open } \\
\text { and Distance } \\
\text { Learning (2011) }\end{array}$ & $\begin{array}{l}\text { Connectivism; networked } \\
\text { learning; learner autonomy; } \\
\text { presence; critical literacies; } \\
\text { massive open online course }\end{array}$ & $\begin{array}{l}\text { Mix methods: } \\
\text { Survey } \\
\text { (descriptive } \\
\text { statistics), focus } \\
\text { group }\end{array}$ & $122(15.3)$ \\
\hline 5 & $\begin{array}{c}\text { Hamid, S.; Waycott, J.; } \\
\text { Kurnia, S.; Chang, S.T. } \\
\text { [36] }\end{array}$ & $\begin{array}{c}\text { Understanding students' } \\
\text { perceptions of the benefits } \\
\text { of online social networking } \\
\text { use for teaching and } \\
\text { learning }\end{array}$ & $\begin{array}{l}\text { Internet and Higher } \\
\text { Education (2015) }\end{array}$ & $\begin{array}{l}\text { Online social networking; } \\
\text { interactions; benefits; } \\
\text { higher education }\end{array}$ & $\begin{array}{l}\text { Qualitative: Focus } \\
\text { group }\end{array}$ & $51(12.8)$ \\
\hline 6 & $\begin{array}{l}\text { Hung, H.T.; Yuen, } \\
\text { S.C.Y. [37] }\end{array}$ & $\begin{array}{l}\text { Educational use of social } \\
\text { networking technology in } \\
\text { higher education }\end{array}$ & $\begin{array}{l}\text { Teaching in Higher } \\
\text { Education (2010) }\end{array}$ & $\begin{array}{l}\text { Classroom community of } \\
\text { practice; sense of classroom } \\
\text { community; social media in } \\
\text { higher education }\end{array}$ & $\begin{array}{l}\text { Quantitative: } \\
\text { Survey } \\
\text { (descriptive } \\
\text { statistics) }\end{array}$ & $30(10.0)$ \\
\hline
\end{tabular}


Table 4. Cont.

\begin{tabular}{|c|c|c|c|c|c|c|}
\hline$\#$ & Authors & Article title & Journal & Main ideas & Methodology & Citations * \\
\hline 7 & $\begin{array}{c}\text { Colas-Bravo, P.; } \\
\text { Gonzalez-Ramirez, T.; } \\
\text { de Pablos-Pons, J. [39] }\end{array}$ & $\begin{array}{c}\text { Young people and social } \\
\text { networks: Motivations and } \\
\text { preferred uses }\end{array}$ & Comunicar (2013) & $\begin{array}{c}\text { Adolescence; social } \\
\text { networks; social capital; } \\
\text { gender differences; social } \\
\text { and psychological } \\
\text { motivations }\end{array}$ & $\begin{array}{l}\text { Quantitative: } \\
\text { Survey } \\
\text { (descriptive } \\
\text { statistics, } \\
\text { chi-square test) }\end{array}$ & $62(10.3)$ \\
\hline 8 & $\begin{array}{l}\text { Veletsianos, G.; } \\
\text { Kimmons, R. [41] }\end{array}$ & $\begin{array}{l}\text { Scholars and faculty } \\
\text { members' lived experiences } \\
\text { in online social networks }\end{array}$ & $\begin{array}{l}\text { Internet and Higher } \\
\text { Education (2013) }\end{array}$ & $\begin{array}{l}\text { Social networking sites; } \\
\text { phenomenology; higher } \\
\text { education faculty; lived } \\
\text { experience; online practices }\end{array}$ & $\begin{array}{c}\text { Qualitative: } \\
\text { Phenomenological } \\
\text { interview }\end{array}$ & $62(10.3)$ \\
\hline 9 & $\begin{array}{l}\text { Trust, T.; Krutka, D.G.; } \\
\text { Carpenter, J.P. [42] }\end{array}$ & $\begin{array}{l}\text { Together we are better: } \\
\text { Professional learning } \\
\text { networks for teachers }\end{array}$ & $\begin{array}{c}\text { Computers \& } \\
\text { Education (2016) }\end{array}$ & $\begin{array}{l}\text { Computer-mediated } \\
\text { communication; learning } \\
\text { communities; lifelong } \\
\text { learning; professional } \\
\text { learning networks }\end{array}$ & $\begin{array}{l}\text { Qualitative: } \\
\text { Survey (thematic } \\
\text { analysis) }\end{array}$ & 103 (11.4) \\
\hline 10 & $\begin{array}{c}\text { De-Marcos, L.; } \\
\text { Garcia-Lopez, E.; } \\
\text { Garcia-Cabot, A. [3] }\end{array}$ & $\begin{array}{l}\text { On the effectiveness of } \\
\text { game-like and social } \\
\text { approaches in learning: } \\
\text { Comparing educational } \\
\text { gaming, gamification, and } \\
\text { social networking }\end{array}$ & $\begin{array}{c}\text { Computers \& } \\
\text { Education (2016) }\end{array}$ & $\begin{array}{l}\text { Gamification; social } \\
\text { approaches in learning; } \\
\text { educational game }\end{array}$ & $\begin{array}{l}\text { Quantitative: } \\
\text { Experimental } \\
\text { design }\end{array}$ & $66(11.0)$ \\
\hline
\end{tabular}

* The citations per year are presented in parentheses. 


\subsection{Discussions: The Classification of Main Research Streams}

Based on observation of the main ideas of the highly-cited articles, three research streams were categorized, including: (1) personal social network relationships, (2) social networking approaches for learning, and (3) the network-based methodologies. First of all, most of the highly-cited EN research was focused on the social networking approaches to promoting learning performance. Researchers have demonstrated that social networking approaches can enhance students' academic achievement, such as CSCL community [1]. When we mentioned the engagement of social networking tools, it is interesting to find that most of the research was conducted in the recent decade (2010-2018). As shown in Table 4, social networking sites, such as MySpace [31] and Facebook [37,38,40], were used as accessibility tools to facilitate learning experiences. Other networking tools, such as online social networks [36], professional learning networks [42], and gamification [3], were also adopted and served for the same purpose.

Next, the second research stream is personal social network relationships. Past research found that personal social networks have some important impacts on school-related matters. Among the relational networks, parents, teachers and students were the three main participants of research. For example, Horvat et al. (2003) pointed out that the parents' networks, especially those related to their social class, will affect their relationship with the school staff [34]. In their study of teachers' social networks, Coburn and Russell (2008) [27] indicated that regional policies can influence teachers' social networking relationships in terms of discussing teaching instruction with peers, and this social relationship can improve their ability to cope with changes in school reform [33], especially in the case of social networking tools, such as professional learning networks (PLNs) [42]. As for the study of student learning efficiency, most studies concluded that students' social networking has demonstrated its efficiency in learning performance (e.g., de-Marcos et al., 2014 [2]).

Finally, special interests in network-based research methods are also noteworthy, such as Bayesian networks and social network analysis (SNA). Garcia et al., (2007) proposed a Bayesian network to the online education system to provide some adaptive recommendations for different students' learning styles. Other researchers used networking attributes (e.g., centrality measures) and networking diagram to visualize the networking phenomenon in several educational environments [29]. For example, Martínez et al. (2003) used density and degree centrality measures as proxy variables for collaborative activities (e.g., sharing information, discussions and solving doubts) [7]. Coburn and Russell (2008) used two network-based variables (i.e., tie span and tie strength) to represent the network structure of teachers' relational network [27]. While Cho et al. (2007) employed more centrality measures (degree, closeness, betweenness, and structural holes) to represent collaborative learning social networks [1], de-Marcos et al. (2014) focused on in-degree centrality to identify the central players in the game-based learning network [2]. In sum, in the first decade, the case study and interview were the most used qualitative analytic technique, while the social network analysis was adopted as the significant quantitative method. In the second decade, quantitative methods (especially survey approach) surpassed other research methods. However, mixed methods and more sophisticated qualitative methods (e.g., phenomenology [41], thematic analysis [42]) were applied to explore more in-depth research contexts.

\section{Conclusions and Research Limitations}

This study has contributed a bibliographic overview of the EN research from 2000 to 2018. These results help researchers explore the rising trends of published articles and authors involved in EN research, identifying the most productive countries and influential journals in the field. Based on observations of changes in highly-cited articles, some discussions have been provided. Moreover, the classification of three main research streams was identified as the directions of future EN research.

Nevertheless, the findings are subject to some methodological limitations. First, the source of the data input is a limitation. The research data used in this study were based on the Web of Science, and are; therefore, focused on rigorous journal publications. Those EN studies published in conference 
proceedings, book chapters, and non-indexed journals were not included in this present study. Second, the method of data analysis may be another limitation. Although bibliometric analysis was used to systematically analyze the EN literature, other content analysis and citation-based methods can be considered in the data analysis to provide a more comprehensive overview of the direction of EN research. For future research, an integrated approach can provide further evidence and analysis to identify the most critical knowledge flows of the literature.

Author Contributions: All authors contributed to the paper. Furthermore, Y.-S.S. acted as a corresponding author. All authors read and approved the final manuscript.

Funding: This study was supported by the Ministry of Science and Technology, Taiwan, R.O.C., under Grant MOST 108-2511-H-019-002, MOST 108-2511-H-019-003, MOST 107-2511-H-019-003, MOST 107-2511-H-008-007 and MOST 107-2511-H-130-003.

Conflicts of Interest: Authors declare no conflicts of interest.

\section{References}

1. Cho, H.; Gay, G.; Davidson, B.; Ingraffea, A. Social networks, communication styles, and learning performance in a CSCL community. Comput. Educ. 2007, 49, 309-329. [CrossRef]

2. De-Marcos, L.; Domínguez, A.; Saenz-de-Navarrete, J.; Pagés, C. An empirical study comparing gamification and social networking on e-learning. Comput. Educ. 2014, 75, 82-91. [CrossRef]

3. De-Marcos, L.; Garcia-Lopez, E.; Garcia-Cabot, A. On the effectiveness of game-like and social approaches in learning: Comparing educational gaming, gamification \& social networking. Comput. Educ. 2016, 95, 99-113. [CrossRef]

4. Lytras, M.; Visvizi, A.; Daniela, L.; Sarirete, A.; Ordonez De Pablos, P. Social networks research for sustainable smart education. Sustainability 2018, 10, 2974. [CrossRef]

5. Csanadi, A.; Eagan, B.; Kollar, I.; Shaffer, D.W.; Fischer, F. When coding-and-counting is not enough: Using epistemic network analysis (ENA) to analyze verbal data in CSCL research. Int. J. Comput.-Supported Collab. Learn. 2018, 13, 419-438. [CrossRef]

6. Dado, M.; Bodemer, D. A review of methodological applications of social network analysis in computer-supported collaborative learning. Educ. Res. Rev. 2017, 22, 159-180. [CrossRef]

7. Martínez, A.; Dimitriadis, Y.; Rubia, B.; Gómez, E.; De La Fuente, P. Combining qualitative evaluation and social network analysis for the study of classroom social interactions. Comput. Educ. 2003, 41, 353-368. [CrossRef]

8. Holcomb, L.B.; Brady, K.P.; Smith, B.V.; Bethany, V. The emergence of "educational networking": Can non-commercial, education-based social networking sites really address the privacy and safety concerns of educators. MERLOT J. Online Learn. Teach. 2010, 6, 475-481.

9. Ninawe, S.S.; Venkataram, P. A method of designing a generic actor model for a professional social network. Human-Cent. Comput. Inf. Sci. 2015, 5, 25. [CrossRef]

10. Macià, M.; García, I. Informal online communities and networks as a source of teacher professional development: A review. Teach. Teach. Educ. 2016, 55, 291-307. [CrossRef]

11. Chugh, R.; Ruhi, U. Social media in higher education: A literature review of Facebook. Educ. Inf. Technol. 2018, 23, 605-616. [CrossRef]

12. Niu, L. Using Facebook for academic purposes: Current literature and directions for future research. J. Educ. Comput. Res. 2019, 56, 1384-1406. [CrossRef]

13. Amara, S.; Macedo, J.; Bendella, F.; Santos, A. Group formation in mobile computer supported collaborative learning contexts: A systematic literature review. Educ. Technol. Soc. 2016, 19, 258-273. [CrossRef]

14. Zhu, M.; Sari, A.; Lee, M.M. A systematic review of research methods and topics of the empirical MOOC literature (2014-2016). Internet High. Educ. 2018, 37, 31-39. [CrossRef]

15. Lee, M.H.; Chai, C.S.; Hong, H.Y. STEM education in Asia Pacific: Challenges and development. Asia-Pac. Educ. Res 2019. [CrossRef]

16. Liu, J.S.; Ho, M.H.C.; Lu, L.Y. Recent themes in social networking service research. PLoS ONE 2017, 12, e0170293. [CrossRef]

17. Pritchard, A. Statistical bibliography or bibliometrics. J. Doc. 1969, 25, 348-349. 
18. Martí-Parreño, J.; Méndez-Ibáñez, E.; Alonso-Arroyo, A. The use of gamification in education: A bibliometric and text mining analysis. J. Comput. Assist. Learn. 2016, 32, 663-676. [CrossRef]

19. Hernández, J.B.; Chalela, S.; Arias, J.V.; Arias, A.V. Research trends in the study of ICT based learning communities: A bibliometric analysis. Eurasia J. Math. Sci. Technol. Educ. 2017, 13, 1539-1562. [CrossRef]

20. Hirsch, J.E. An index to quantify an individual's scientific research output. Proc. Natl. Acad. Sci. USA 2005, 102, 16569-16572. [CrossRef]

21. Egghe, L. Theory and practise of the g-index. Scientometrics 2006, 69, 131-152. [CrossRef]

22. White, H.D.; McCain, K.W. Visualizing a discipline: An author co-citation analysis of information science, 1972-1995. J. Am. Soc. Inf. Sci. 1998, 49, 327-355. [CrossRef]

23. Tang, K.Y.; Chou, T.L.; Tsai, C.C. A content analysis of computational thinking research: An international publication trends and research typology. Asia-Pac. Educ. Res. 2019. [CrossRef]

24. Amirkhanian, Y.A.; Kelly, J.A.; Kabakchieva, E.; McAuliffe, T.L.; Vassileva, S. Evaluation of a social network HIV prevention intervention program for young men who have sex with men in Russia and Bulgaria. AIDS Educ. Prev. 2003, 15, 205-220. [CrossRef]

25. Yoshikawa, H.; Alan-David Wilson, P.; Chae, D.H.; Cheng, J.F. Do family and friendship networks protect against the influence of discrimination on mental health and HIV risk among Asian and Pacific Islander gay men. AIDS Educ. Prev. 2004, 16, 84-100. [CrossRef]

26. Huang, E.; Marlin, R.W.; Young, S.D.; Medline, A.; Klausner, J.D. Using Grindr, a smartphone socialnetworking application, to increase HIV self-testing among Black and Latino men who have sex with men in Los Angeles, 2014. AIDS Educ. Prev. 2016, 28, 341-350. [CrossRef]

27. Coburn, C.E.; Russell, J.L. District policy and teachers' social networks. Educ. Eval. Policy Anal. 2008, 30, 203-235. [CrossRef]

28. Ball, S.J. Privatising education, privatising education policy, privatising educational research: Network governance and the 'competition state'. J. Educ. Policy 2009, 24, 83-99. [CrossRef]

29. García, P.; Amandi, A.; Schiaffino, S.; Campo, M. Evaluating Bayesian networks' precision for detecting students' learning styles. Comput. Educ. 2007, 49, 794-808. [CrossRef]

30. De Laat, M.; Lally, V.; Lipponen, L.; Simons, R.J. Investigating patterns of interaction in networked learning and computer-supported collaborative learning: A role for Social Network Analysis. Int. J. Comput.-Supported Collab. Learn. 2007, 2, 87-103. [CrossRef]

31. Greenhow, C.; Robelia, B. Informal learning and identity formation in online social networks. Learn. Media Technol. 2009, 34, 119-140. [CrossRef]

32. Zurita, G.; Nussbaum, M. A constructivist mobile learning environment supported by a wireless handheld network. J. Comput. Assist. Learn. 2004, 20, 235-243. [CrossRef]

33. Penuel, W.R.; Riel, M.; Krause, A.E.; Frank, K.A. Analyzing teachers' professional interactions in a school as social capital: A social network approach. Teach. Coll. Rec. 2009, 111, 124-163.

34. Horvat, E.M.; Weininger, E.B.; Lareau, A. From social ties to social capital: Class differences in the relations between schools and parent networks. Am. Educ. Res. J. 2003, 40, 319-351. [CrossRef]

35. Roblyer, M.D.; McDaniel, M.; Webb, M.; Herman, J.; Witty, J.V. Findings on Facebook in higher education: A comparison of college faculty and student uses and perceptions of social networking sites. Internet High. Educ. 2010, 13, 134-140. [CrossRef]

36. Hamid, S.; Waycott, J.; Kurnia, S.; Chang, S. Understanding students' perceptions of the benefits of online social networking use for teaching and learning. Internet High. Educ. 2015, 26, 1-9. [CrossRef]

37. Hung, H.T.; Yuen, S.C.Y. Educational use of social networking technology in higher education. Teach. High. Educ. 2010, 15, 703-714. [CrossRef]

38. Yu, A.Y.; Tian, S.W.; Vogel, D.; Kwok, R.C.W. Can learning be virtually boosted? An investigation of online social networking impacts. Comput. Educ. 2010, 55, 1494-1503. [CrossRef]

39. Colás Bravo, M.P.; González Ramírez, T.; Pablos Pons, J.D. Young people and social networks: Motivations and preferred uses. Comunicar 2013, 40, 15-23. [CrossRef]

40. Kop, R. The challenges to connectivist learning on open online networks: Learning experiences during a massive open online course. Int. Rev. Res. Open Distrib. Learn. 2011, 12, 19-38. [CrossRef] 
41. Veletsianos, G.; Kimmons, R. Scholars and faculty members' lived experiences in online social networks. Internet High. Educ. 2013, 16, 43-50. [CrossRef]

42. Trust, T.; Krutka, D.G.; Carpenter, J.P. "Together we are better": Professional learning networks for teachers. Comput. Educ. 2016, 102, 15-34. [CrossRef]

(c) (

(C) 2019 by the authors. Licensee MDPI, Basel, Switzerland. This article is an open access article distributed under the terms and conditions of the Creative Commons Attribution (CC BY) license (http://creativecommons.org/licenses/by/4.0/). 